\title{
KAJIAN MODEL SPRINGATE PADA KELOMPOK SAHAM JAKARTA ISLAMIC INDEX PERIODE 2013 - 2017
}

\author{
Windu Anggara \\ Pascasarjana Program Studi Ekonomi Syariah, Universitas Islam Negeri Sumatera \\ Utara Medan \\ Email: winduanggara23@gmail.com
}

M. Syukri Albani Nst

Universitas Islam Negeri Sumatera Utara Medan

Email: msyukrialbani@uinsu.ac.id

\begin{abstract}
This study aims to find out and analyze the health condition of the company based on the magnitude of the predicted value using financial ratios in the Springate model. The research method used is descriptive analysis method with a quantitative approach. The research population is all companies listed in Jakarta Islamic Index (JII), amounting to 30 companies, using purposive sampling. The analysis technique used is the analysis of financial statements with the Springate model (S-Score) which aims to find out companies that experience financial distress and bankruptcy. The results showed that there were several companies in 2013 and 2014 that experienced bankruptcy, namely $16.67 \%$, then increased to $26.67 \%$ in 2016, and the most significant occurred in 2015 and 2017, namely $30.00 \%$.
\end{abstract}

Keywords: Springate model (S-Score), financial distress and bankruptcy

\begin{abstract}
Abstrak
Penelitian ini bertujuan untuk mengetahui dan menganalisis kondisi kesehatan perusahaan berdasarkan besaran nilai prediksi dengan menggunakan rasio-rasio keuangan yang ada dalam model Springate. Metode penelitian yang digunakan adalah metode analisis deskriptif dengan pendekatan kuantitatif. Populasi penelitian adalah seluruh perusahaan yang listing pada JII yang berjumlah 30 perusahaan, menggunakan purposive sampling. Teknik analisis yang digunakan adalah analisis terhadap laporan keuangan dengan model Springate (S-Score) yang bertujuan untuk mengetahui perusahaan yang mengalami financial distress dan kebangkrutan. Hasil penelitian menunjukkan terdapat beberapa perusahaan pada 2013 dan 2014 yang mengalami distress (bankrupt) yaitu 16,67\%, kemudian mengalami peningkatan menjadi $26,67 \%$ pada 2016 , dan yang paling signifikan terjadi pada 2015 dan 2017 yaitu 30,00\%.
\end{abstract}

Kata kunci : model Springate (S-Score), financial distress dan kebangkrutan

\section{Pendahuluan}

Kondisi makroekonomi yang cukup positif pada tahun 2017 karena didukung oleh permodalan yang tinggi dan likuiditas yang memadai untuk mampu 
mengantisipasi terjadinya risiko dan mendukung ekspansi usaha merupakan wujud perbaikan pertumbuhan ekonomi global, namun cenderung stagnan terhadap pertumbuhan bisnis industri di Indonesia.

Membaiknya kondisi perekonomian global dan Indonesia berdampak pada kinerja Indeks Harga Saham Gabungan (IHSG) di Bursa Efek Indonesia, yang sepanjang tahun 2017 menguat 20\% ke posisi rekor tertinggi 6.355,7. Hal tersebut membuat perbaikan kondisi ekonomi Indonesia tersebut di atas memberikan ruang bagi Bank Indonesia (BI) untuk melakukan pelonggaran moneter dengan menurunkan suku bunga acuan sebesar 4,25\% yang tercatat per Desember 2017. ${ }^{1}$

Perkembangan tersebut tidak menutup kemungkinan juga dikarenakan munculnya beberapa instrumen syariah di Bursa Efek Indonesia (BEI) sejak tahun 1997 yang semakin diminati hingga saat ini. Diawali dengan lahirnya reksadana syariah yang diprakarsai oleh Danareksa. Selanjutnya, disusun indeks yang secara khusus terdiri dari komponen saham-saham syariah yaitu Jakarta Islamic Indeks $(\mathrm{JII}){ }^{2}$

Krisis ekonomi yang sempat melanda Indonesia pada akhir tahun 1997-1998 membuat nilai tukar rupiah merosot, kemudian perekonomian Indonesia menurun drastis dan berubah menjadi krisis ekonomi yang berkepanjangan. Krisis ekonomi berkembang semakin parah karena kesalahan mendasar dalam perekonomian nasional di tingkat mikro yang dilakukan oleh sektor swasta dan pengelolaan badan usaha milik negara yang sangat tidak efisien. ${ }^{3}$ Kondisi tersebut mengakibatkan banyak perusahaan-perusahaan publik yang bangkrut dan terlikuidasi. Data di Bursa Efek Jakarta (BEJ) menunjukkan bahwa di Indonesia pada akhir tahun buku 1997 terdapat 210 perusahan dari 279 perusahaan publik yang mengalami penurunan laba bersih sekitar 97\% dibandingkan dengan laba bersih tahun 1996. Dan 75\% dari 210 perusahan publik tersebut mengalami rugi bersih yang cukup besar. ${ }^{4}$ Hal tersebut mengakibatkan perusahaan tidak mampu bertahan dengan situasi kesulitan keuangan dikarenakan laba atau keuntungan merupakan salah satu tujuan utama perusahaan dalam menjalankan aktivitasnya tidak mampu diperoleh secara maksimal, dan berdampak serius bagi perusahaan. Dalam jangka pendek mungkin tidak terlalu berpengaruh, kecuali perusahaan mengalami kerugian yang cukup besar. Namun, dalam jangka panjang dapat mengakibatkan banyak kerugian, dengan 
191 AT-TAWASSUTH:Jurnal Ekonomi Islam, Volume VI No. II Juli-Desember 2021: 189 - 212

kemungkinan perusahaan akan mengurangi jumlah tenaga kerja atau mungkin yang lebih parah yaitu perusahaan mengalami kebangkrutan karena kesulitan keuangan, serta tidak mampu membiayai aktivitas perusahaan dalam hal operasionalnya untuk menghasilkan laba. ${ }^{5}$

Salah satu indikator kesulitan keuangan perusahaan dapat dilihat dari kegagalan perusahaan menjalankan aktivitas perusahaan untuk menghasilkan laba. Berdasarkan pada laporan keuangan yang dipublikasikan BEI, pada rentang waktu penelitian 2013 - 2017 terdapat beberapa perusahaan yang konsisten listing dalam kelompok perusahaan Jakarta Islamic Index (JII) mengalami penurunan laba bersih bahkan peningkatan rugi bersih selama beberapa tahun terakhir. Adapun beberapa perusahaan yang mengalami kerugian selama 5 (lima) tahun periode penelitian dapat di lihat pada tabel 1 sebagai berikut :

Tabel 1. Daftar Perusahaan Jakarta Islamic Index (JII) Mengalami Penurunan Laba Bersih Maupun Peningkatan Rugi Bersih Periode 2013 - 2017

(dalam jutaan Rupiah)

\begin{tabular}{|r|l|r|r|r|r|r|}
\hline \multirow{2}{*}{ No } & Kode & \multicolumn{5}{|c|}{ Tahun } \\
\cline { 3 - 7 } & Perusahaan & \multicolumn{1}{|c|}{$\mathbf{2 0 1 3}$} & $\mathbf{2 0 1 4}$ & \multicolumn{1}{c|}{$\mathbf{2 0 1 5}$} & \multicolumn{1}{c|}{$\mathbf{2 0 1 6}$} & \multicolumn{1}{c|}{$\mathbf{2 0 1 7}$} \\
\hline 1 & ANTM & 532.800 & $(743.530)$ & $(1.440 .853)$ & 64.806 & $(331.480)$ \\
\hline 2 & BKDP & $(20.784)$ & 7.032 & $(28.227)$ & $(28.948)$ & $(43.170)$ \\
\hline 3 & BMSR & $(27.921)$ & $(162.825)$ & $(19.569)$ & $(6.810)$ & $(3.098)$ \\
\hline 4 & CENT & $(31.386)$ & $(43.660)$ & $(53.392)$ & $(29.811)$ & $(119.048)$ \\
\hline 5 & ELTY & $(232.250)$ & 69.984 & $(724.167)$ & $(547.265)$ & $(19.090)$ \\
\hline 6 & EXCL & 1.032 .817 & $(803.714)$ & $(25.338)$ & 375.516 & 375.244 \\
\hline 7 & IKAI & $(43.089)$ & $(25.518)$ & $(108.888)$ & $(145.359)$ & $(43.578)$ \\
\hline 8 & TRIL & $(36.568)$ & $(36.568)$ & $(8.175)$ & $(7.141)$ & $(10.010)$ \\
\hline 9 & ZBRA & $(4.277)$ & $(6.617)$ & $(8.351)$ & $(12.642)$ & 376 \\
\hline
\end{tabular}

(Sumber : Data diolah 2018, Laporan Keuangan 2013-2017 diakses www.idx.co.id)

Berdasarkan pada tabel 1.1 di atas tampak bahwa beberapa perusahaan yang listing dalam kelompok saham Jakarta Islamic Index (JII) mengalami penurunan laba bersih maupun peningkatan rugi bersih dengan peringkat 3 (tiga) teratas diantaranya yaitu : 1) PT. Aneka Tambang (Persero) Tbk. atau kode perusahaan ANTM mengalami kerugian terbesar selama periode penelitian yaitu pada tahun 2015 sebesar Rp 1.440.852.896.174, 2) PT. XL Axiata Tbk. sebesar Rp 803.714.393.289,- pada tahun 2014 dan 3) PT. Bakrieland Development Tbk. sebesar Rp 724.166.901.246,- pada tahun 2015. 
Mengingat terjadinya kebangkrutan suatu perusahaan ditandai dengan kesulitan keuangan (financial distress), jika kondisi tersebut tidak ditangani dengan tepat, maka kebangkrutan atau likuidasi yang akan terjadi. Berdasarkan hal tersebut, tidak menutup kemungkinan bagi perusahaan untuk mengantisipasi hal tersebut dengan melakukan analisis prediksi kesehatan keuangan, yang salah satunya menggunakan analisis prediksi model Springate (S-Score).

Penelitian ini bertujuan untuk mengetahui dan menganalisis kondisi perusahaan berdasarkan besaran nilai prediksi kinerja keuangan pada perusahaan yang listing dalam kelompok perusahaan yang masuk dalam saham Jakarta Islamic Index (JII) periode 2013 - 2017 dengan menggunakan rasio-rasio keuangan yang ada dalam model Springate. Hasil penelitian akan menunjukkan beberapa perusahaan yang listing dalam kelompok perusahaan yang masuk dalam saham Jakarta Islamic Index (JII) periode 2013 - 2017 yang mengalami financial distress maupun kebangkrutan (bankruptcy).

\section{Tinjauan Pustaka}

\section{a. Laporan Keuangan}

S. Munawir dan Kasmir, sama menulis dan membahas mengenai analisa laporan keuangan menunjukkan kondisi keuangan perusahaan pada saat ini atau dalam suatu periode tertentu. ${ }^{6}$ Maksud laporan keuangan yang menunjukkan kondisi perusahaan saat ini adalah merupakan kondisi terkini. Kondisi perusahaan terkini adalah keadaan keuangan perusahaan pada tanggal dan periode tertentu. Biasanya laporan keuangan dibuat per periode, misalnya tiga bulan, atau enam bulan untuk kepentingan internal perusahaan. Sedangkan, untuk laporan lebih luas dilakukan satu tahun sekali. $^{7}$

Secara umum laporan keuangan merupakan hasil akhir dari proses akuntansi. Dalam perspektif Islam akuntansi bukanlah sesuatu yang baru meskipun pencatatan keuangan yang dikenal selama ini diakui berkembang dari peradaban barat. Hal ini ditunjukkan bahwa eksistensi akuntansi dalam Islam dapat di lihat pada pedoman suci umat Islam yaitu Al-Qur'an. ${ }^{8}$ Sumber mengenai akuntansi dalam Islam terdapat pada QS. Al-Baqarah [2] ayat 282 yang menunjukkan bahwa Islam menganjurkan untuk menulis setiap transaksi yang dilakukan terlebih yang belum tunai atau tuntas. Tujuan dari perintah penulisan tersebut adalah untuk menjaga 
keadilan dan terhindar dari keraguan sehingga semua pihak tidak ada yang dirugikan. Ayat tersebut kemudian menjadi landasan hukum terhadap konsep akuntansi syariah. ${ }^{9}$

Mengenai laporan keuangan yang merupakan hasil dari proses akuntansi dipersiapkan atau dibuat oleh pihak manajemen untuk memberikan gambaran atau progress report secara periodik. Karena itu laporan keuangan bersifat historis dan menyeluruh. Sebagai suatu progress report laporan keuangan terdiri atas data-data yang dihasilkan dari kombinasi antara fakta yang telah dicatat (recorded fact), prinsip - prinsip dan kebiasaan - kebiasaan di dalam akuntansi (accounting convention and postulate), dan pendapat pribadi (personal judgement). ${ }^{10}$

Laporan keuangan perusahaan harus dibuat dan disusun sesuai dengan aturan atau standar yang berlaku. Hal ini dilakukan agar laporan keuangan mudah dibaca dan dimengerti. Laporan keuangan yang disajikan perusahaan tidak hanya penting bagi manajemen dan pemilik perusahaan saja, tetapi juga penting bagi pihak-pihak lainnya. Pemakai laporan keuangan ini meliputi investor saat ini dan investor potensial, karyawan, pemberi pinjaman, pemasok dan kreditur usaha lainnya, pelanggan, pemerintah dan lembaga-lembaganya dan masyarakat. ${ }^{11}$

Laporan keuangan menyediakan data yang relative mentah. Pihak yang berkepentingan membutuhkan informasi dari data mentah tersebut yang kemudian diolah. Informasi yang dibutuhkan tergantung dari tujuan yang ingin dicapai. Sedangkan tujuan yang ingin dicapai akan tergantung dari siapa yang membutuhkan informasi, dan kapan informasi tersebut dibutuhkan. ${ }^{12}$ Agar suatu laporan keuangan menjadi lebih berarti sehingga dapat dipahami dan dimengerti oleh berbagai pihak, perlu dilakukan analisis laporan keuangan.

Analisa laporan keuangan berarti menguraikan pos-pos laporan keuangan menjadi unit informasi yang lebih kecil. Dengan cara melihat hubungan yang bersifat signifikan antara satu dengan yang lain, baik antara data kuantitatif maupun data non kuantitatif. Tujuannya untuk mengetahui kondisi keuangan secara lebih mendalam karena sangat penting untuk menghasilkan keputusan yang tepat. ${ }^{13}$ Analisis laporan 
keuangan dapat diartikan sebagai proses penguraian data (informasi) yang terdapat dalam laporan keuangan menjadi bagian-bagian tersendiri, menelaah setiap bagian dan mempelajari hubungan-hubungan antar bagian agar memperoleh pemahaman yang tepat tentang informasi tersebut.

\section{b. Model Springate}

Model Springate adalah model yang dapat digunakan untuk menguji suatu kebangkrutan (bankruptcy) yang merupakan persoalan serius dan memakan biaya. Oleh karena itu, jika ada early warning system yang bisa mendeteksi potensi awal terjadinya kebangkrutan maka manajemen akan sangat terbantu. Manajemen akan dapat melakukan perbaikan sedini mungkin untuk menghindari kebangkrutan.Ada beberapa indikator yang bisa dipakai untuk memprediksi gejala kebangkrutan. Indikator tersebut bisa berupa indikator internal (dari dalam perusahaan) dan indikator eksternal (dari luar perusahaan). Beberapa contoh indikator internal perusahaan adalah aliran kas perusahaan, strategi perusahaan, laporan keuangan, trend penjualan, maupun kemampuan manajemen. Sedangkan indikator eksternal bisa diambil dari pasar keuangan, informasi dari pihak yang berkaitan seperti pemasok, dealer, dan konsumen. ${ }^{14}$

Untuk melakukan suatu prediksi terhadap kesulitan keuangan (financial distress) maupun kebangkrutan dalam penelitian ini dilakukan dengan menggunakan analisis multivariate, yaitu penggunaan dua variabel atau lebih secara bersama-sama ke dalam suatu persamaan. Dalam hal ini, peneliti menggunakan analisis rasio dikembangkan Gordon L.V Springate (model Springate) yang dianggap mampu dalam memprediksi kesulitan keuangan (financial distress) maupun kebangkrutan. Springate merumuskan modelnya sebagai berikut $:^{15}$

$$
S-\text { Score }=1,03 \mathrm{~A}+3,07 \mathrm{~B}+0,66 \mathrm{C}+0,4 \mathrm{D}
$$

Keterangan :
A = Rasio Modal Kerja terhadap Total Asset
B = Rasio Laba Sebelum Bunga dan Pajak terhadap Total Aset
C = Rasio Laba Sebelum Bunga dan Pajak terhadap Utang Lancar
$\mathrm{D}$ = Rasio Penjualan terhadap Total Asset

Adapun kriteria prediksi financial distress dengan menggunakan model Springate dapat diketahui apabila perusahaan dikatakan akan 
bangkrut atau “distress” jika memiliki skor kurang dari 0,862 (S-Score < 0,862). Sebaliknya, jika hasil perhitungan $S$ - Score melebihi atau sama dengan 0,862 (S-Score $\geq 0,862)$ maka perusahaan diklasifikasikan perusahaan yang sehat secara keuangan atau "Non-Distress".

\section{Penelitian Sebelumnya}

Karena kegiatan menganalisis laporan keuangan pada kelompok saham Jakarta Islamic Index (JII) dengan menggunakan model Springate masih relatif sedikit, tidak ada studi khusus yang membahas efektivitas kegiatan ini dalam hal keakuratan dalam menghasilkan suatu ukuran yang dapat dijadikan patokan secara mendalam mengenai hasil penelitian yang diperoleh. Beberapa studi yang mampu menunjukkan hasil yang cukup relevan, diantaranya : Rizki Amalia Burhanuddin (2015), berjudul “Analisis Penggunaan Metode Altman Z-Score dan Model Springate untuk Mengetahui Potensi Terjadinya Financial Distress pada Perusahaan Manufaktur Sektor Industri Dasar dan Kimia Sub Sektor Semen Periode 2009-2013”. Galuh Tri Pembekti (2014) berjudul “Analisis Ketepatan Model Altman, Springate, Zmijewski, dan Grover untuk Financial Distress (Studi pada Perusahaan yang Masuk dalam Daftar Efek Syariah Tahun 2009-2012)”. Jeni Jesika (2013) berjudul “Analisis Tingkat Kebangkrutan dengan Menggunakan Metode Altman Z-Score, Springate, dan Internal Growth Rate pada PT Bumi Resources Tbk Periode 2008 - 2012”. Selain itu, penelitian yang sedikit berbeda dilakukan lakukan oleh Vera Intanie Dewi dan Felisca (2011) dengan judul “Analisis Tipe Kesalahan dalam Memprediksi Kepailitan Perusahaan dengan Menggunakan Metode Altman Z-Score pada Perusahaan Food and Beverages yang Terdaftar di Bursa Efek Indonesia".

Penelitian selanjutnya mengenai adanya potensi (indikasi) financial distress perusahaan dilakukan Ohlson (1980) menggunakan analisis Logit, Zmijewski (1984) menggunakan analisis Probit, ${ }^{16}$ dan Zavgren (1985) menggunakan analisis Logit. Ohlson dan Zavgren meskipun sama-sama menggunakan analisis Logit, namun yang membedakannya adalah Zavgren mempertimbangkan sektor dan aset perusahaan sedangkan Ohlson hanya mempertimbangkan ukuran perusahaan.

Mengingat pentingnya prediksi financial distress dan kebangkrutan untuk mengetahui kondisi perusahaan, telah dilakukan beberapa penelitian serupa saat 
ini mengenai financial distress dengan berbagai model, diantaranya yang dilakukan Shaukat dan Afandi (2015) yang mengukur rasio Altman yang paling besar mengakibatkan kebangkrutan. ${ }^{17}$ Shahdouts (2015) melakukan penelitian di Iran dengan hasil penelitian menunjukan perbedaan yang signifikan antara kedua model. Altman dengan tingkat akurasi 95,5\% dan Zavgren 18,2\%, sehingga Altman lebih baik digunakan dari pada Zavgren. ${ }^{18}$ Berbeda dengan penelitian Fakhri Husein (2014) yang menyatakan Altman mempunyai akurasi yang lemah dibanding model Springate dalam memprediksi financial distress. ${ }^{19}$

\section{Kerangka Pemikiran}

Dalam rasio yang dikombinasikan dalam suatu formula yang dirumuskan Gordon L.V. Springate yang selanjutnya terkenal dengan istilah model Springate (S-Score). Model Springate yang sudah dikenal mampu untuk memprediksi financial distress dan kebangkrutan perusahaan dim as mendatang dengan melihat dari sisi laporan keuangan, dapat digunakan sebagai suatu sarana bagi pihak yang berkepentingan dalam menganalisis dan mengevaluasi kondisi dan kinerja suatu perusahaan. Adapun kerangka pemikiran yang dapat dikembangkan terlihat pada gambar 1 berikut ini :

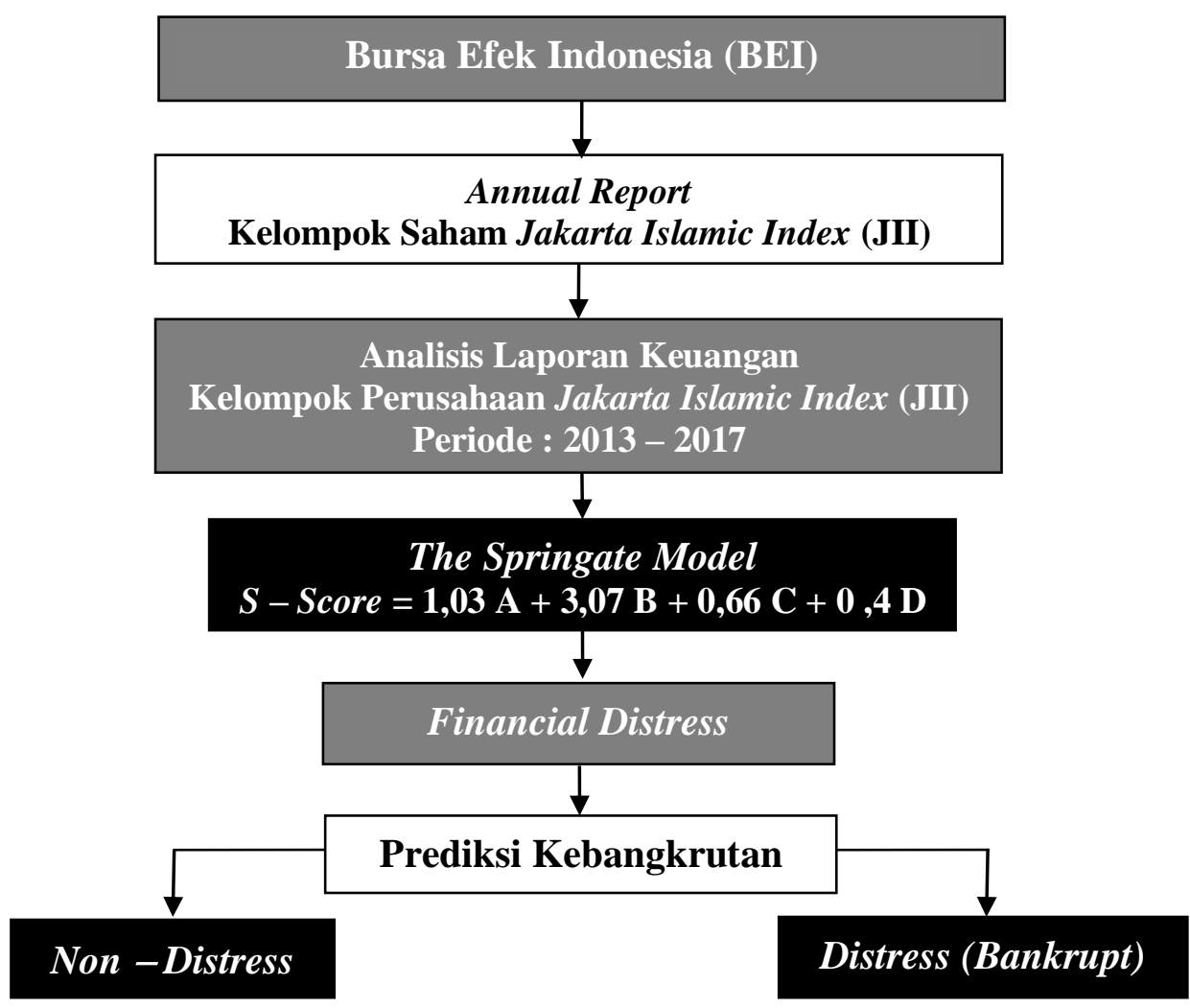

Gambar 1. Model Kerangka Pemikiran Penelitian 
197 AT-TAWASSUTH:Jurnal Ekonomi Islam, Volume VI No. II

Juli-Desember 2021: 189 - 212

\section{Metode Penelitian}

Metode penelitian yang digunakan adalah metode analisis deskriptif dengan pendekatan kuantitatif. Populasi penelitian adalah seluruh perusahaan yang listing pada kelompok saham Jakarta Islamic Index (JII) periode penelitian 2013 - 2017 yang berjumlah 30 perusahaan. Teknik pengambilan sampel menggunakan purposive sampling. Teknik analisis yang digunakan adalah analisis terhadap laporan keuangan dengan model Springate ( $S$-Score) yang bertujuan untuk mengetahui perusahaan yang mengalami financial distress dan kebangkrutan.

\section{Hasil Dan Pembahasan}

\section{Rasio $\mathrm{A}=$ Working Capital to Total Assest}

Hasil dari perhitungan nilai rasio modal kerja terhadap total aktiva perusahaan atas laporan keuangan yang diterbitkan perusahan-perusahaan yang konsisten listing dalam kelompok saham Jakarta Islamic Index (JII) adalah sebagai berikut :

Tabel 2. Hasil Perhitungan Rasio $\mathrm{A}=$ Working Capital to Total Assests

\begin{tabular}{|c|l|c|c|c|c|c|}
\hline \multirow{2}{*}{ No } & \multirow{2}{*}{ Kode } & \multicolumn{5}{|c|}{ Tahun } \\
\cline { 3 - 7 } & Perusahaan & $\mathbf{2 0 1 3}$ & $\mathbf{2 0 1 4}$ & $\mathbf{2 0 1 5}$ & $\mathbf{2 0 1 6}$ & $\mathbf{2 0 1 7}$ \\
\hline 1 & AALI & $-0,138$ & $-0,092$ & $-0,033$ & 0,004 & 0,078 \\
\hline 2 & ADRO & 0,089 & 0,077 & 0,107 & 0,145 & 0,177 \\
\hline 3 & AKRA & 0,077 & 0,036 & 0,159 & 0,100 & 0,201 \\
\hline 4 & ASII & 0,080 & 0,100 & 0,118 & 0,081 & 0,091 \\
\hline 5 & ASRI & $-0,064$ & 0,023 & $-0,056$ & $-0,017$ & $-0,040$ \\
\hline 6 & BMTR & 0,288 & 0,321 & 0,130 & 0,055 & 0,184 \\
\hline 7 & BSDE & 0,314 & 0,203 & 0,296 & 0,282 & 0,226 \\
\hline 8 & CPIN & 0,413 & 0,266 & 0,255 & 0,269 & 0,272 \\
\hline 9 & EXCL & $-0,052$ & $-0,033$ & $-0,095$ & $-0,140$ & $-0,143$ \\
\hline 10 & HRUM & 0,426 & 0,456 & 0,507 & 0,521 & 0,583 \\
\hline 11 & ICBP & 0,309 & 0,296 & 0,300 & 0,315 & 0,308 \\
\hline 12 & INDF & 0,171 & 0,213 & 0,193 & 0,119 & 0,158 \\
\hline 13 & INTP & 0,511 & 0,462 & 0,378 & 0,373 & 0,326 \\
\hline 14 & ITMG & 0,175 & 0,157 & 0,193 & 0,248 & 0,346 \\
\hline 15 & JSMR & $-0,039$ & $-0,021$ & $-0,104$ & $-0,106$ & $-0,076$ \\
\hline 16 & KLBF & 0,429 & 0,462 & 0,466 & 0,477 & 0,470 \\
\hline 17 & LPKR & 0,613 & 0,642 & 0,695 & 0,671 & 0,637 \\
\hline 18 & LSIP & 0,150 & 0,129 & 0,079 & 0,120 & 0,180 \\
\hline
\end{tabular}


Windu Anggara: Kajian Model Springate... |198

\begin{tabular}{|l|l|c|c|c|c|c|}
19 & MAPI & 0,060 & 0,152 & 0,254 & 0,228 & 0,196 \\
\hline 20 & MNCN & 0,541 & 0,572 & 0,462 & 0,171 & 0,349 \\
\hline 21 & MMPA & $-0,064$ & $-0,118$ & $-0,043$ & 0,086 & 0,067 \\
\hline 22 & PGAS & 0,207 & 0,124 & 0,162 & 0,192 & 0,213 \\
\hline 23 & PTBA & 0,361 & 0,259 & 0,158 & 0,178 & 0,300 \\
\hline 24 & PWON & 0,093 & 0,095 & 0,052 & 0,073 & 0,150 \\
\hline 25 & SMGR & 0,152 & 0,166 & 0,103 & 0,050 & 0,102 \\
\hline 26 & SMRA & 0,103 & 0,046 & 0,154 & 0,214 & 0,133 \\
\hline 27 & TLKM & 0,036 & 0,008 & 0,075 & 0,044 & 0,011 \\
\hline 28 & UNTR & 0,231 & 0,287 & 0,340 & 0,373 & 0,277 \\
\hline 29 & UNVR & $-0,201$ & $-0,177$ & $-0,223$ & $-0,256$ & $-0,243$ \\
\hline 30 & WIKA & 0,055 & 0,065 & 0,100 & 0,279 & 0,196 \\
\hline \multicolumn{2}{|l|}{ Rata - rata } & $\mathbf{0 , 1 7 8}$ & $\mathbf{0 , 1 7 3}$ & $\mathbf{0 , 1 7 3}$ & $\mathbf{0 , 1 7 2}$ & $\mathbf{0 , 1 9 1}$ \\
\hline
\end{tabular}

(Sumber : Data Diolah, 2018)

Pada tabel 2 di atas, dapat dilihat perolehan nilai rata - rata hasil perhitungan rasio modal kerja terhadap total aset pada perusahaan yang konsisten listing dalam kelompok saham Jakarta Islamic Index (JII) periode 2013 - 2017 yaitu 0,$178 ; 0,173 ; 0,173 ; 0,172 ;$ dan 0,191 . Dengan nilai rata-rata perolehan di atas -1 dan dibawah 0 (nol) maka dapat dikatakan perusahaan-perusahaan tersebut memiliki likuiditas yang rendah. Berdasarkan pada hasil perhitungan rasio modal kerja terhadap total aset yang telah dilakukan pada tabel 4.1 dapat diketahui bahwa nilai modal kerja negatif menjadikan likuiditas perusahaan yang konsisten listing dalam kelompok saham Jakarta Islamic Index (JII) periode 2013 - 2017 sangat rendah, karena total utang lancar yang dimiliki melebihi total aset lancar perusahaan. Dengan modal kerja bersih yang negatif kemungkinan besar suatu perusahaan akan menghadapi masalah dalam menutupi kewajiban jangka pendeknya karena tidak tersedianya aktiva lancar yang cukup untuk menutupi kewajiban yang ada. Sebaliknya, perusahaan dengan modal kerja bersih yang bernilai positif akan jarang sekali menghadapi kesulitan dalam melunasi kewajibannya. Hasil penelitian ini memiliki kesesuaian dengan penelitian yang dilakukan oleh Burhanuddin (2015) dan Pembekti (2014) yang menyebutkan dalam hasil penelitian mereka dengan pengelolaan data terhadap 30 perusahaan, terdapat 15 perusahaan dalam kategori financial distress dan 15 perusahaan lainnya non-financial distress. Selain itu, dalam rasio model Springate yang digunakan untuk memprediksi financial distress yang menunjukkan hasil singnifikan kuat dalam memprediksi financial distress suatu perusahaan. 
199 AT-TAWASSUTH:Jurnal Ekonomi Islam, Volume VI No. II Juli-Desember 2021: 189 - 212

\section{Rasio B = EBIT to Total Assets}

Hasil dari perhitungan nilai rasio laba sebelum bunga dan pajak dengan total aktiva perusahaan atas laporan keuangan yang diterbitkan perusahanperusahaan yang konsisten listing dalam kelompok saham Jakarta Islamic Index (JII) adalah sebagai berikut :

Tabel 3. Hasil Perhitungan Rasio $\mathrm{B}=$ Earning Before Interest and Tax to Total Assets

\begin{tabular}{|c|l|c|c|c|c|c|}
\hline \multirow{2}{*}{ No } & Kode & \multicolumn{5}{|c|}{ Tahun } \\
\cline { 3 - 7 } & Perusahaan & $\mathbf{2 0 1 3}$ & $\mathbf{2 0 1 4}$ & $\mathbf{2 0 1 5}$ & $\mathbf{2 0 1 6}$ & $\mathbf{2 0 1 7}$ \\
\hline 1 & AALI & 0,178 & 0,204 & 0,060 & 0,097 & 0,123 \\
\hline 2 & ADRO & 0,080 & 0,080 & 0,057 & 0,091 & 0,144 \\
\hline 3 & AKRA & 0,081 & 0,106 & 0,130 & 0,112 & 0,027 \\
\hline 4 & ASII & 0,134 & 0,122 & 0,086 & 0,019 & 0,028 \\
\hline 5 & ASRI & 0,083 & 0,085 & 0,049 & 0,040 & 0,068 \\
\hline 6 & BMTR & 0,099 & 0,090 & 0,045 & 0,081 & 0,101 \\
\hline 7 & BSDE & 0,066 & 0,155 & 0,082 & 0,070 & 0,126 \\
\hline 8 & CPIN & 0,229 & 0,115 & 0,113 & 0,191 & 0,036 \\
\hline 9 & EXCL & 0,294 & 0,011 & 0,020 & 0,036 & 0,031 \\
\hline 10 & HRUM & 0,135 & 0,024 & $-0,040$ & 0,075 & 0,162 \\
\hline 11 & ICBP & 0,146 & 0,146 & 0,163 & 0,179 & 0,170 \\
\hline 12 & INDF & 0,086 & 0,091 & 0,083 & 0,109 & 0,104 \\
\hline 13 & INTP & 0,250 & 0,236 & 0,205 & 0,138 & 0,080 \\
\hline 14 & ITMG & 0,223 & 0,201 & 0,119 & 0,159 & 0,267 \\
\hline 15 & JSMR & 0,080 & 0,095 & 0,018 & 0,078 & 0,057 \\
\hline 16 & KLBF & 0,230 & 0,227 & 0,200 & 0,205 & 0,197 \\
\hline 17 & LPKR & 0,052 & 0,086 & 0,035 & 0,039 & 0,023 \\
\hline 18 & LSIP & 0,125 & 0,138 & 0,022 & 0,082 & 0,103 \\
\hline 19 & MAPI & 0,141 & 0,113 & 0,058 & 0,077 & 0,088 \\
\hline 20 & MNCN & 0,253 & 0,191 & 0,130 & 0,165 & 0,178 \\
\hline 21 & MMPA & 0,624 & 0,618 & 0,609 & 0,528 & 0,445 \\
\hline 22 & PGAS & 0,252 & 0,170 & 0,086 & 0,070 & 0,067 \\
\hline 23 & PTBA & 0,211 & 0,184 & 0,167 & 0,153 & 0,281 \\
\hline 24 & PWON & 0,163 & 0,189 & 0,089 & 0,100 & 0,103 \\
\hline 25 & SMGR & 0,170 & 0,168 & 0,163 & 0,123 & 0,072 \\
\hline 26 & SMRA & 0,084 & 0,090 & 0,099 & 0,073 & 0,066 \\
\hline 27 & TLKM & 0,224 & 0,219 & 0,204 & 0,228 & 0,229 \\
\hline 28 & UNTR & 0,120 & 0,114 & 0,073 & 0,113 & 0,139 \\
\hline 29 & UNVR & 0,565 & 0,544 & 0,505 & 0,520 & 0,502 \\
\hline 30 & WIKA & 0,086 & 0,084 & 0,060 & 0,055 & 0,047 \\
\hline Rata - rata & $\mathbf{0 , 1 8 2}$ & $\mathbf{0 , 1 6 3}$ & $\mathbf{0 , 1 2 3}$ & $\mathbf{0 , 1 3 4}$ & $\mathbf{0 , 1 3 5}$ \\
\hline & & & & $5 u m b$ & D \\
\hline
\end{tabular}

(Sumber : Data Diolah, 2018) 
Pada tabel 3, di atas diperoleh hasil hampir sebagian besar perusahaan mempunyai nilai positif dalam perhitungan rasio laba sebelum bunga dan pajak dengan total aktiva. Hal ini menunjukkan bahwa perusahaan yang konsisten listing pada Daftar Efek Syariah dalam kelompok perusahaan yang masuk dalam perhitungan saham Jakarta Islamic Index (JII) periode 2013 - 2017 adalah saham dari perusahaan - perusahaan yang tercatat paling liquid dan memiliki kredibilitas sangat baik di Bursa Efek Indonesia berdasarkan rata - rata nilai transaksi harian di pasar regular tertinggi. Pada tabel di atas tampak bahwa nilai rata - rata hasil perhitungan rasio laba sebelum bunga dan pajak dengan total aktiva perusahaan yang konsisten listing dalam kelompok saham Jakarta Islamic Index (JII) periode 2013 - 2017 yaitu : 0,182;0,163;0,123;0,134; dan 0,135. Hal ini dapat di ambil suatu kesimpulan bahwa semakin besar nilai hasil perhitungan rasio laba/rugi sebelum bunga dan pajak dengan total aktiva semakin baik suatu perusahaan dalam menghasilkan laba. Sebaliknya, semakin kecil nilai hasil perhitungan rasio laba/rugi sebelum bunga dan pajak dengan total aktiva menunjukkan ketidakmampuan perusahaan untuk menghasilkan laba. Hasil penelitian ini tidak bersinggungan dengan penelitian yang dilakukan Burhanuddin (2015), Pembekti (2014) serta Jesika (2013) dimana dalam mengklasifikasikan kebangkrutan didasarkan pada hasil perhitungan rasio masing - masing model yang diterapkan dalam penelitian sebelumnya. Hal ini diperkuat dengan temuan Shahdouts (2015) yang melakukan penelitian di Iran dengan hasil penelitian menunjukan perbedaan yang signifikan antara kedua model prediksi financial distress dan kebangkrutan, dimana model Altman dengan tingkat akurasi 95,5\% dan hanya Zavgren 18,2\%, sehingga Altman lebih baik digunakan daripada Zavgren. Berbeda dengan penelitian Husein (2014) yang menyatakan Altman mempunyai akurasi yang lemah jika dibandingkan dengan model Springate dalam memprediksi financial distress dan kebangkrutan.

\section{Rasio $\mathrm{C}=$ EBIT to Current Liabilites}

Hasil dari perhitungan nilai rasio laba sebelum bunga dan pajak dengan

utang lancar perusahaan atas laporan keuangan yang diterbitkan perusahanperusahaan yang konsisten listing dalam kelompok saham Jakarta Islamic Index (JII) adalah sebagai berikut : 
201 AT-TAWASSUTH:Jurnal Ekonomi Islam, Volume VI No. II Juli-Desember 2021: 189 - 212

Tabel 4. Hasil Perhitungan Rasio $\mathrm{C}=$ Earning Before Interest and Taxes to Current Liabilities

\begin{tabular}{|c|l|c|c|c|c|c|}
\hline \multirow{2}{*}{ No } & \multirow{2}{*}{ Kode } & \multicolumn{5}{|c|}{ Tahun } \\
\cline { 3 - 7 } & Perusahaan & $\mathbf{2 0 1 3}$ & $\mathbf{2 0 1 4}$ & $\mathbf{2 0 1 5}$ & $\mathbf{2 0 1 6}$ & $\mathbf{2 0 1 7}$ \\
\hline 1 & AALI & 0,711 & 0,919 & 0,369 & 0,597 & 1,330 \\
\hline 2 & ADRO & 0,693 & 0,660 & 0,750 & 0,925 & 1,271 \\
\hline 3 & AKRA & 0,179 & 0,254 & 0,405 & 0,305 & 0,085 \\
\hline 4 & ASII & 0,403 & 0,391 & 0,275 & 0,055 & 0,083 \\
\hline 5 & ASRI & 0,323 & 0,515 & 0,245 & 0,238 & 0,445 \\
\hline 6 & BMTR & 0,566 & 0,895 & 0,184 & 0,272 & 0,649 \\
\hline 7 & BSDE & 0,335 & 0,807 & 0,478 & 0,474 & 0,763 \\
\hline 8 & CPIN & 1,547 & 0,535 & 0,496 & 0,834 & 0,176 \\
\hline 9 & EXCL & 1,491 & 0,045 & 0,075 & 0,137 & 0,116 \\
\hline 10 & HRUM & 0,778 & 0,133 & $-0,472$ & 0,585 & 1,292 \\
\hline 11 & ICBP & 0,667 & 0,591 & 0,720 & 0,799 & 0,785 \\
\hline 12 & INDF & 0,344 & 0,343 & 0,304 & 0,466 & 0,423 \\
\hline 13 & INTP & 2,038 & 2,486 & 2,110 & 1,304 & 0,662 \\
\hline 14 & ITMG & 0,791 & 0,722 & 0,494 & 0,808 & 1,108 \\
\hline 15 & JSMR & 0,463 & 0,704 & 0,088 & 0,223 & 0,181 \\
\hline 16 & KLBF & 0,986 & 1,180 & 1,160 & 1,346 & 1,472 \\
\hline 17 & LPKR & 0,334 & 0,569 & 0,301 & 0,262 & 0,149 \\
\hline 18 & LSIP & 1,243 & 1,594 & 0,341 & 0,998 & 2,419 \\
\hline 19 & MAPI & 0,276 & 0,256 & 0,166 & 0,197 & 0,219 \\
\hline 20 & MNCN & 1,515 & 2,916 & 1,805 & 0,559 & 1,834 \\
\hline 21 & MMPA & 0,970 & 0,836 & 0,971 & 1,002 & 0,925 \\
\hline 22 & PGAS & 1,227 & 0,967 & 0,834 & 0,588 & 0,906 \\
\hline 23 & PTBA & 1,091 & 0,762 & 0,573 & 0,564 & 1,367 \\
\hline 24 & PWON & 0,533 & 0,808 & 0,379 & 0,449 & 0,490 \\
\hline 25 & SMGR & 0,989 & 1,097 & 0,943 & 0,668 & 0,398 \\
\hline 26 & SMRA & 0,227 & 0,273 & 0,423 & 0,358 & 0,228 \\
\hline 27 & TLKM & 1,008 & 1,610 & 0,955 & 1,031 & 1,001 \\
\hline 28 & UNTR & 0,472 & 0,423 & 0,247 & 0,393 & 0,402 \\
\hline 29 & UNVR & 0,923 & 0,877 & 0,785 & 0,801 & 0,758 \\
\hline 30 & WIKA & 0,148 & 0,159 & 0,112 & 0,116 & 0,082 \\
\hline Ratayyyyyy- rata & $\mathbf{0 , 7 7 6}$ & $\mathbf{0 , 8 1 1}$ & $\mathbf{0 , 5 5 0}$ & $\mathbf{0 , 5 7 9}$ & $\mathbf{0 , 7 3 4}$ \\
\hline
\end{tabular}

(Sumber : Data Diolah, 2018)

Berdasarkan tabel 4 di atas, dapat dilihat perolehan nilai rata - rata hasil perhitungan rasio laba sebelum bunga dan pajak dengan utang lancar perusahaan yang konsisten listing dalam kelompok saham Jakarta Islamic Index (JII) periode 2013 - 2017 yaitu : 0,776; 0,811;0,550; 0,579 dan 0,734. Dengan nilai minimum rasio laba sebelum bunga dan pajak terhadap utang lancar adalah sebesar $-0,472$ 
yaitu PT. Harum Energy Tbk. pada tahun 2015 sedangkan nilai maksimum rasio laba sebelum bunga dan pajak terhadap utang lancar adalah sebesar 2,916 yaitu PT. Media Nusantara Citra Tbk. pada tahun 2014. Hal ini dapat disimpulkan bahwa semakin tinggi perolehan nilai laba/rugi sebelum bunga dan pajak terhadap utang lancar menunjukkan semakin rendah jumlah utang yang diakumulasikan terhadap modal perusahaan. Sebaliknya, semakin rendah perolehan nilai laba/rugi sebelum bunga dan pajak terhadap utang lancar menunjukkan semakin tinggi jumlah utang yang diakumulasikan terhadap modal perusahaan. Apabila nilai buku ekuitas perusahaan lebih kecil daripada jumlah utangnya maka perusahaan terebut rawan terhadap kondisi financial distress yang berujung pada kebangkrutan. Jika disandingkan dengan hasil penelitian ini tidak menutup kemungkinan memiliki kesesuaian dengan penelitian yang dilakukan Burhanuddin (2015), Pembekti (2014) serta Jesika (2013) dimana dalam mengklasifikasikan kebangkrutan didasarkan pada hasil perhitungan rasio yang diperkuat dengan temuan Shahdouts (2015). Namun dari yang diperoleh Shahdouts (2015) berbeda dengan penelitian Husein (2014) mengenai hasil model Altman mempunyai akurasi yang lemah jika dibandingkan dengan model Springate dalam memprediksi financial distress dan kebangkrutan. Sedangkan Rafique (2015) menilai berdasarkan pada titik cut-off masing-masing yang diterapkan dengan hasil tingkat akurasi disebabkan karena keadaan perusahaan dan ekonomi suatu Negara yang berbeda-beda.

\section{Rasio D = Sales to Total Assets}

Hasil dari perhitungan nilai rasio penjualan terhadap total aset perusahaan atas laporan keuangan yang diterbitkan perusahan-perusahaan yang konsisten listing dalam kelompok saham Jakarta Islamic Index (JII) adalah sebagai berikut :

Tabel 5. Hasil Perhitungan Rasio D = Sales to Total Assets

\begin{tabular}{|c|l|c|c|c|c|c|}
\hline \multirow{2}{*}{ No } & \multirow{2}{*}{ Kode } & \multicolumn{5}{|c|}{ Tahun } \\
\cline { 3 - 7 } & Perusahaan & $\mathbf{2 0 1 3}$ & $\mathbf{2 0 1 4}$ & $\mathbf{2 0 1 5}$ & $\mathbf{2 0 1 6}$ & $\mathbf{2 0 1 7}$ \\
\hline 1 & AALI & 0,847 & 0,879 & 0,607 & 0,583 & 0,694 \\
\hline 2 & ADRO & 0,488 & 0,518 & 0,451 & 0,387 & 0,478 \\
\hline 3 & AKRA & 1,527 & 1,519 & 1,300 & 0,961 & 0,258 \\
\hline 4 & ASII & 0,906 & 0,855 & 0,750 & 0,160 & 0,174 \\
\hline 5 & ASRI & 0,255 & 0,215 & 0,149 & 0,135 & 0,153 \\
\hline 6 & BMTR & 0,476 & 0,420 & 0,398 & 0,425 & 0,391 \\
\hline 7 & BSDE & 0,092 & 0,199 & 0,172 & 0,171 & 0,225 \\
\hline 8 & CPIN & 1,632 & 1,397 & 1,201 & 1,581 & 0,490 \\
\hline
\end{tabular}


203 AT-TAWASSUTH:Jurnal Ekonomi Islam, Volume VI No. II Juli-Desember 2021: 189 - 212

\begin{tabular}{|c|l|c|c|c|c|c|}
9 & EXCL & 0,529 & 0,369 & 0,389 & 0,389 & 0,406 \\
\hline 10 & HRUM & 1,763 & 1,075 & 0,655 & 0,525 & 0,709 \\
\hline 11 & ICBP & 1,172 & 1,199 & 1,195 & 1,189 & 1,126 \\
\hline 12 & INDF & 0,717 & 0,740 & 0,698 & 0,811 & 0,798 \\
\hline 13 & INTP & 0,702 & 0,692 & 0,644 & 0,510 & 0,500 \\
\hline 14 & ITMG & 1,472 & 1,486 & 1,349 & 1,130 & 1,244 \\
\hline 15 & JSMR & 0,366 & 0,288 & 0,268 & 0,311 & 0,443 \\
\hline 16 & KLBF & 1,414 & 1,398 & 1,306 & 1,272 & 1,215 \\
\hline 17 & LPKR & 0,213 & 0,309 & 0,216 & 0,231 & 0,192 \\
\hline 18 & LSIP & 0,518 & 0,546 & 0,010 & 0,407 & 0,486 \\
\hline 19 & MAPI & 1,247 & 1,361 & 1,353 & 1,324 & 1,427 \\
\hline 20 & MNCN & 0,678 & 0,490 & 0,445 & 0,473 & 0,468 \\
\hline 21 & MMPA & 2,300 & 2,325 & 2,316 & 2,037 & 1,847 \\
\hline 22 & PGAS & 0,695 & 0,548 & 0,472 & 0,429 & 0,472 \\
\hline 23 & PTBA & 0,960 & 0,883 & 0,820 & 0,757 & 0,886 \\
\hline 24 & PWON & 0,326 & 0,231 & 0,246 & 0,277 & 0,245 \\
\hline 25 & SMGR & 0,565 & 0,597 & 0,706 & 0,591 & 0,568 \\
\hline 26 & SMRA & 0,224 & 0,258 & 0,300 & 0,259 & 0,260 \\
\hline 27 & TLKM & 0,648 & 0,632 & 0,617 & 0,648 & 0,646 \\
\hline 28 & UNTR & 0,889 & 0,881 & 0,800 & 0,712 & 0,785 \\
\hline 29 & UNVR & 2,421 & 2,417 & 2,319 & 2,392 & 2,179 \\
\hline 30 & WIKA & 0,944 & 0,783 & 0,695 & 0,500 & 0,573 \\
\hline Rata $-\mathbf{r a t a}$ & $\mathbf{0 , 9 0 0}$ & $\mathbf{0 , 8 5 0}$ & $\mathbf{0 , 7 6 2}$ & $\mathbf{0 , 7 1 9}$ & $\mathbf{0 , 6 7 8}$ \\
\hline
\end{tabular}

(Sumber : Data Diolah, 2018)

Berdasarkan pada nilai rasio penjualan terhadap total aset terendah, perusahaan yang konsisten listing dalam kelompok saham Jakarta Islamic Index (JII) periode 2013 - 2017 dengan nilai minimum rasio penjualan terhadap total aktiva sebesar 0,010 adalah PT. PP London Sumatera Indonesia Tbk, pada tahun 2015. Sedangkan perusahaan yang konsisten listing dalam kelompok saham Jakarta Islamic Index (JII) periode 2013 - 2017 dengan nilai maksimum rasio penjualan terhadap total aktiva sebesar 2,421 adalah PT. Unilever Indonesia Tbk., pada tahun 2013. Dengan perolehan nilai rata - rata hasil perhitungan rasio laba sebelum bunga dan pajak dengan utang lancar perusahaan yang konsisten listing dalam kelompok saham Jakarta Islamic Index (JII) periode 2013 - 2017 yaitu : 0,$900 ; 0,850 ; 0,762 ; 0,719$ dan 0,678. Hal ini dapat disimpulkan bahwa semakin besar nilai rasio penjualan terhadap total aktiva menunjukkan kemampuan perusahaan yang konsisten listing dalam kelompok saham Jakarta Islamic Index (JII) periode 2013 - 2017 semakin baik dalam menghadapi persaingan. Namun 
sebaliknya, jika nilai rasio penjualan terhadap total aset semakin rendah, hal ini menunjukkan indikasi ketidakmampuan perusahaan yang konsisten listing dalam kelompok saham Jakarta Islamic Index (JII) periode 2013 - 2017 dalam menghadapi persaingan. Secara mendalam, dengan rasio ini dapat menunjukkan tingkat efisiensi penggunaan keseluruhan aktiva perusahaan yang konsisten listing dalam kelompok saham Jakarta Islamic Index (JII) dalam menghasilkan volume penjualan. Rasio ini juga mampu mengukur seberapa efisien aktiva tersebut setelah dimanfaatkan untuk memperoleh penghasilan. Semakin tinggi nilai rasio penjualan terhadap total aset berarti semakin efisien penggunaan keseluruhan aktiva perusahaan dalam menghasilkan volume penjualan (total assets trun over). Mengenai adanya potensi (indikasi) financial distress berkaitan dengan aspek penjualan perusahaan, hal ini berkaitan dengan penelitian yang dilakukan Ohlson (1980) dan Zavgren (1985) yang menggunakan analisis Logit, serta Zmijewski (1984) menggunakan analisis Probit. Ohlson dan Zavgren meskipun sama-sama menggunakan analisis Logit, namun yang membedakannya adalah Zavgren mempertimbangkan sektor (bidang) perusahaan dan aset perusahaan sedangkan Ohlson hanya mempertimbangkan ukuran (besar/kecil) perusahaan. Berdasarkan hal tersebut mengindikasikan kaitan dengan penelitian ini bahwa besarnya nilai rasio yang dihasilkan dari jumlah penjualan terhadap total aktiva menunjukkan kemampuan perusahaan semakin baik dalam menghadapi persaingan. Namun, berkenaan dengan sektor perusahaan yang tercatat dalam kelompok saham Jakarta Islamic Index (JII) hanya perusahaan dengan kegiatan massif yang melakukan produksi dan pemasaran yang mampu memiliki nilai maksimum pada rasio penjualan terhadap total aktiva perusahaan. Selain itu, berdasarkan kecilnya hasil nilai rasio yang diperoleh dari penjualan terhadap total aktiva ini akan mempengaruhi tingkat kepercayaan investor terhadap kinerja manajemen perusahaan dalam memperoleh pendapatan. Hal inilah yang dialami sektor perusahaan dalam kelompok saham Jakarta Islamic Index (JII) yang tidak massif melakukan produksi dan pemasaran dalam kegiatan usahanya.

Adapun hasil perhitungan rasio - rasio yang ada dalam model Springate (S-Score) pada perusahaan atas laporan keuangan yang diterbitkan perusahaan yang konsisten listing dalam kelompok saham Jakarta Islamic Index (JII) periode 2013 - 2017 dapat disajikan dalam tabel 6 berikut :

Tabel 6. Hasil Rekapitulasi Perhitungan Model Springate (S-Score) 
205 AT-TAWASSUTH:Jurnal Ekonomi Islam, Volume VI No. II Juli-Desember 2021: 189 - 212

\begin{tabular}{|c|c|c|c|c|c|c|}
\hline \multirow{2}{*}{ No } & \multirow{2}{*}{$\begin{array}{c}\text { Kode } \\
\text { Perusahaan }\end{array}$} & \multicolumn{5}{|c|}{ Hasil Perhitungan Model Springate (S-Score) } \\
\hline & & 2013 & 2014 & 2015 & 2016 & 2017 \\
\hline 1 & AALI & $\begin{array}{c}\mathbf{1 , 2 1 3} \\
\text { Non-Distress }\end{array}$ & $\begin{array}{c}\mathbf{1 , 4 8 8} \\
\text { Non-Distress }\end{array}$ & $\begin{array}{c}\mathbf{0 , 6 3 8} \\
\text { Distress }\end{array}$ & $\begin{array}{c}\mathbf{0 , 9 3 0} \\
\text { Non-Distress }\end{array}$ & $\begin{array}{c}\mathbf{1 , 6 1 3} \\
\text { Non-Distress }\end{array}$ \\
\hline 2 & ADRO & $\begin{array}{c}\mathbf{0 , 9 8 8} \\
\text { Non-Distress }\end{array}$ & $\begin{array}{c}\mathbf{0 , 9 6 8} \\
\text { Non-Distress }\end{array}$ & $\begin{array}{c}\mathbf{0 , 9 6 1} \\
\text { Non-Distress }\end{array}$ & $\begin{array}{c}\mathbf{1 , 1 9 6} \\
\text { Non-Distress }\end{array}$ & $\begin{array}{c}\mathbf{1 , 6 5 5} \\
\text { Non-Distress }\end{array}$ \\
\hline 3 & AKRA & $\begin{array}{c}\mathbf{1 , 0 5 6} \\
\text { Non-Distress }\end{array}$ & $\begin{array}{c}\mathbf{1 , 1 3 8} \\
\text { Non-Distress }\end{array}$ & $\begin{array}{c}\mathbf{1 , 3 4 9} \\
\text { Non-Distress }\end{array}$ & $\begin{array}{c}\mathbf{1 , 0 3 2} \\
\text { Non-Distress }\end{array}$ & $\begin{array}{c}\mathbf{0 , 4 5 0} \\
\text { Distress }\end{array}$ \\
\hline 4 & ASII & $\begin{array}{c}\mathbf{1 , 1 2 2} \\
\text { Non-Distress }\end{array}$ & $\begin{array}{c}\mathbf{1 , 0 7 7} \\
\text { Non-Distress }\end{array}$ & $\begin{array}{c}\mathbf{0 , 8 6 6} \\
\text { Non-Distress }\end{array}$ & $\begin{array}{c}\mathbf{0 , 2 4 1} \\
\text { Distress }\end{array}$ & $\begin{array}{c}\mathbf{0 , 3 0 4} \\
\text { Distress }\end{array}$ \\
\hline 5 & ASRI & $\begin{array}{c}\mathbf{0 , 5 0 5} \\
\text { Distress }\end{array}$ & $\begin{array}{c}\mathbf{0 , 7 1 1} \\
\text { Distress }\end{array}$ & $\begin{array}{c}\mathbf{0 , 3 1 4} \\
\text { Distress }\end{array}$ & $\begin{array}{c}\mathbf{0 , 3 1 7} \\
\text { Distress }\end{array}$ & $\begin{array}{c}\mathbf{0 , 5 2 1} \\
\text { Distress }\end{array}$ \\
\hline 6 & BMTR & $\begin{array}{c}\mathbf{1 , 1 6 4} \\
\text { Non-Distress } \\
\end{array}$ & $\begin{array}{c}\mathbf{1 , 3 6 7} \\
\text { Non-Distress } \\
\end{array}$ & $\begin{array}{c}\mathbf{0 , 5 5 2} \\
\text { Distress }\end{array}$ & $\begin{array}{c}\mathbf{0 , 6 5 4} \\
\text { Distress }\end{array}$ & $\begin{array}{c}\mathbf{1 , 0 8 3} \\
\text { Non-Distress } \\
\end{array}$ \\
\hline 7 & BSDE & $\begin{array}{c}\mathbf{0 , 7 8 4} \\
\text { Distress }\end{array}$ & $\begin{array}{c}\mathbf{1 , 2 9 8} \\
\text { Non-Distress }\end{array}$ & $\begin{array}{c}\mathbf{0 , 9 3 9} \\
\text { Non-Distress }\end{array}$ & $\begin{array}{c}\mathbf{0 , 8 8 7} \\
\text { Non-Distress }\end{array}$ & $\begin{array}{c}\mathbf{1 , 2 1 3} \\
\text { Non-Distress }\end{array}$ \\
\hline 8 & CPIN & $\begin{array}{c}\mathbf{2 , 8 0 2} \\
\text { Non-Distress } \\
\end{array}$ & $\begin{array}{c}\mathbf{1 , 5 3 8} \\
\text { Non-Distress } \\
\end{array}$ & $\begin{array}{c}\mathbf{1 , 4 1 9} \\
\text { Non-Distress } \\
\end{array}$ & $\begin{array}{c}\mathbf{2 , 0 4 7} \\
\text { Non-Distress } \\
\end{array}$ & $\begin{array}{c}\mathbf{0 , 7 0 3} \\
\text { Distress } \\
\end{array}$ \\
\hline 9 & EXCL & $\begin{array}{c}\mathbf{2 , 0 4 4} \\
\text { Non-Distress } \\
\end{array}$ & $\begin{array}{c}\mathbf{0 , 1 7 7} \\
\text { Distress } \\
\end{array}$ & $\begin{array}{c}\mathbf{0 , 1 6 8} \\
\text { Distress } \\
\end{array}$ & $\begin{array}{c}\mathbf{0 , 2 1 2} \\
\text { Distress } \\
\end{array}$ & $\begin{array}{c}\mathbf{0 , 1 8 8} \\
\text { Distress } \\
\end{array}$ \\
\hline 10 & HRUM & $\begin{array}{c}\mathbf{2 , 0 7 3} \\
\text { Non-Distress } \\
\end{array}$ & $\begin{array}{c}\mathbf{1 , 0 6 0} \\
\text { Non-Distress } \\
\end{array}$ & $\begin{array}{c}\mathbf{0 , 3 4 8} \\
\text { Distress } \\
\end{array}$ & $\begin{array}{c}\mathbf{1 , 3 6 2} \\
\text { Non-Distress } \\
\end{array}$ & $\begin{array}{c}\mathbf{2 , 2 3 6} \\
\text { Non-Distress } \\
\end{array}$ \\
\hline 11 & ICBP & $\begin{array}{c}\mathbf{1 , 6 7 7} \\
\text { Non-Distress } \\
\end{array}$ & $\begin{array}{c}\mathbf{1 , 6 2 4} \\
\text { Non-Distress } \\
\end{array}$ & $\begin{array}{c}\mathbf{1 , 7 6 2} \\
\text { Non-Distress } \\
\end{array}$ & $\begin{array}{c}\mathbf{1 , 8 7 6} \\
\text { Non-Distress } \\
\end{array}$ & $\begin{array}{c}\mathbf{1 , 8 0 7} \\
\text { Non-Distress }\end{array}$ \\
\hline 12 & INDF & $\begin{array}{c}\mathbf{0 , 9 5 5} \\
\text { Non-Distress }\end{array}$ & $\begin{array}{c}\mathbf{1 , 0 2 0} \\
\text { Non-Distress }\end{array}$ & $\begin{array}{c}\mathbf{0 , 9 3 3} \\
\text { Non-Distress }\end{array}$ & $\begin{array}{c}\mathbf{1 , 0 8 9} \\
\text { Non-Distress }\end{array}$ & $\begin{array}{c}\mathbf{1 , 0 8 0} \\
\text { Non-Distress }\end{array}$ \\
\hline 13 & INTP & $\begin{array}{c}\mathbf{2 , 9 1 9} \\
\text { Non-Distress }\end{array}$ & $\begin{array}{c}\mathbf{3 , 1 1 7} \\
\text { Non-Distress }\end{array}$ & $\begin{array}{c}\mathbf{2 , 6 7 0} \\
\text { Non-Distress }\end{array}$ & $\begin{array}{c}\mathbf{1 , 8 7 2} \\
\text { Non-Distress }\end{array}$ & $\begin{array}{c}\mathbf{1 , 2 1 7} \\
\text { Non-Distress } \\
\end{array}$ \\
\hline 14 & ITMG & $\begin{array}{c}\mathbf{1 , 9 7 7} \\
\text { Non-Distress } \\
\end{array}$ & $\begin{array}{c}\mathbf{1 , 8 5 0} \\
\text { Non-Distress }\end{array}$ & $\begin{array}{c}\mathbf{1 , 4 3 1} \\
\text { Non-Distress }\end{array}$ & $\begin{array}{c}\mathbf{1 , 7 3 0} \\
\text { Non-Distress } \\
\end{array}$ & $\begin{array}{c}\mathbf{2 , 4 0 4} \\
\text { Non-Distress }\end{array}$ \\
\hline 15 & JSMR & $\begin{array}{c}\mathbf{0 , 6 5 9} \\
\text { Distress }\end{array}$ & $\begin{array}{c}\mathbf{0 , 8 5 1} \\
\text { Distress }\end{array}$ & $\begin{array}{c}\mathbf{0 , 1 1 4} \\
\text { Distress }\end{array}$ & $\begin{array}{c}\mathbf{0 , 4 0 2} \\
\text { Distress }\end{array}$ & $\begin{array}{c}\mathbf{0 , 3 9 4} \\
\text { Distress }\end{array}$ \\
\hline 16 & KLBF & $\begin{array}{c}\mathbf{2 , 3 6 5} \\
\text { Non-Distress } \\
\end{array}$ & $\begin{array}{c}\mathbf{2 , 5 0 9} \\
\text { Non-Distress }\end{array}$ & $\begin{array}{c}\mathbf{2 , 3 8 3} \\
\text { Non-Distress } \\
\end{array}$ & $\begin{array}{c}\mathbf{2 , 5 1 7} \\
\text { Non-Distress }\end{array}$ & $\begin{array}{c}\mathbf{2 , 5 4 7} \\
\text { Non-Distress }\end{array}$ \\
\hline 17 & LPKR & $\begin{array}{c}\mathbf{1 , 0 9 6} \\
\text { Non-Distress }\end{array}$ & $\begin{array}{c}\mathbf{1 , 4 2 5} \\
\text { Non-Distress }\end{array}$ & $\begin{array}{c}\mathbf{1 , 1 0 9} \\
\text { Non-Distress }\end{array}$ & $\begin{array}{c}\mathbf{1 , 0 7 7} \\
\text { Non-Distress }\end{array}$ & $\begin{array}{c}\mathbf{0 , 9 0 2} \\
\text { Non-Distress }\end{array}$ \\
\hline 18 & LSIP & $\begin{array}{c}\mathbf{1 , 5 6 7} \\
\text { Non-Distress } \\
\end{array}$ & $\begin{array}{c}\mathbf{1 , 8 2 6} \\
\text { Non-Distress } \\
\end{array}$ & $\begin{array}{c}\mathbf{0 , 3 7 7} \\
\text { Non-Distress } \\
\end{array}$ & $\begin{array}{c}\mathbf{1 , 1 9 9} \\
\text { Non-Distress } \\
\end{array}$ & $\begin{array}{c}\mathbf{2 , 2 9 3} \\
\text { Non-Distress } \\
\end{array}$ \\
\hline 19 & MAPI & $\begin{array}{c}\mathbf{1 , 1 7 5} \\
\text { Non-Distress } \\
\end{array}$ & $\begin{array}{c}\mathbf{1 , 2 1 7} \\
\text { Non-Distress } \\
\end{array}$ & $\begin{array}{c}\mathbf{1 , 0 9 0} \\
\text { Non-Distress } \\
\end{array}$ & $\begin{array}{c}\mathbf{1 , 1 3 1} \\
\text { Non-Distress } \\
\end{array}$ & $\begin{array}{c}\mathbf{1 , 1 8 6} \\
\text { Non-Distress } \\
\end{array}$ \\
\hline 20 & $\mathrm{MNCN}$ & $\begin{array}{c}\mathbf{2 , 6 0 6} \\
\text { Non-Distress } \\
\end{array}$ & $\begin{array}{c}\mathbf{3 , 2 9 6} \\
\text { Non-Distress } \\
\end{array}$ & $\begin{array}{c}\mathbf{2 , 2 4 3} \\
\text { Non-Distress } \\
\end{array}$ & $\begin{array}{c}\mathbf{1 , 2 4 0} \\
\text { Non-Distress }\end{array}$ & $\begin{array}{c}\mathbf{2 , 3 0 3} \\
\text { Non-Distress } \\
\end{array}$ \\
\hline 21 & MMPA & $\begin{array}{c}\mathbf{3 , 4 1 0} \\
\text { Non-Distress }\end{array}$ & $\begin{array}{c}\mathbf{3 , 2 5 8} \\
\text { Non-Distress }\end{array}$ & $\begin{array}{c}\mathbf{3 , 3 9 3} \\
\text { Non-Distress }\end{array}$ & $\begin{array}{c}\mathbf{3 , 1 8 5} \\
\text { Non-Distress }\end{array}$ & $\begin{array}{c}\mathbf{2 , 7 8 4} \\
\text { Non-Distress }\end{array}$ \\
\hline 22 & PGAS & $\begin{array}{c}\mathbf{2 , 0 7 5} \\
\text { Non-Distress }\end{array}$ & $\begin{array}{c}\mathbf{1 , 5 0 6} \\
\text { Non-Distress }\end{array}$ & $\begin{array}{c}\mathbf{1 , 1 7 0} \\
\text { Non-Distress }\end{array}$ & $\begin{array}{c}\mathbf{0 , 9 7 2} \\
\text { Non-Distress }\end{array}$ & $\begin{array}{c}\mathbf{1 , 2 1 2} \\
\text { Non-Distress }\end{array}$ \\
\hline 23 & PTBA & $\begin{array}{c}\mathbf{2 , 1 2 5} \\
\text { Non-Distress }\end{array}$ & $\begin{array}{c}\mathbf{1 , 6 8 8} \\
\text { Non-Distress }\end{array}$ & $\begin{array}{c}\mathbf{1 , 3 8 2} \\
\text { Non-Distress }\end{array}$ & $\begin{array}{c}\mathbf{1 , 3 2 9} \\
\text { Non-Distress }\end{array}$ & $\begin{array}{c}\mathbf{2 , 4 2 8} \\
\text { Non-Distress }\end{array}$ \\
\hline 24 & PWON & $\begin{array}{c}\mathbf{1 , 0 7 9} \\
\text { Non-Distress }\end{array}$ & $\begin{array}{c}\mathbf{1 , 3 0 3} \\
\text { Non-Distress }\end{array}$ & $\begin{array}{c}\mathbf{0 , 6 7 7} \\
\text { Distress }\end{array}$ & $\begin{array}{c}\mathbf{0 , 7 9 0} \\
\text { Distress }\end{array}$ & $\begin{array}{c}\mathbf{0 , 8 9 3} \\
\text { Non-Distress }\end{array}$ \\
\hline 25 & SMGR & $\begin{array}{c}\mathbf{1 , 5 5 7} \\
\text { Non-Distress }\end{array}$ & $\begin{array}{c}\mathbf{1 , 6 4 8} \\
\text { Non-Distress }\end{array}$ & $\begin{array}{c}\mathbf{1 , 5 1 2} \\
\text { Non-Distress }\end{array}$ & $\begin{array}{c}\mathbf{1 , 1 0 7} \\
\text { Non-Distress }\end{array}$ & $\begin{array}{c}\mathbf{0 , 8 1 5} \\
\text { Distress }\end{array}$ \\
\hline
\end{tabular}


Windu Anggara: Kajian Model Springate... 206

\begin{tabular}{|c|c|c|c|c|c|c|}
\hline 26 & SMRA & $\begin{array}{c}\mathbf{0 , 6 0 3} \\
\text { Distress } \\
\end{array}$ & $\begin{array}{c}\mathbf{0 , 6 0 7} \\
\text { Distress }\end{array}$ & $\begin{array}{c}\mathbf{0 , 8 6 3} \\
\text { Distress } \\
\end{array}$ & $\begin{array}{c}\mathbf{0 , 7 8 3} \\
\text { Distress }\end{array}$ & $\begin{array}{c}\mathbf{0 , 5 9 5} \\
\text { Distress }\end{array}$ \\
\hline 27 & TLKM & $\begin{array}{c}\mathbf{1 , 6 4 9} \\
\text { Non-Distress }\end{array}$ & $\begin{array}{c}\mathbf{1 , 9 9 6} \\
\text { Non-Distress }\end{array}$ & $\begin{array}{c}\mathbf{1 , 5 7 9} \\
\text { Non-Distress }\end{array}$ & $\begin{array}{c}\mathbf{1 , 6 8 6} \\
\text { Non-Distress }\end{array}$ & $\begin{array}{c}\mathbf{1 , 6 3 3} \\
\text { Non-Distress }\end{array}$ \\
\hline 28 & UNTR & $\begin{array}{c}\mathbf{1 , 2 7 3} \\
\text { Non-Distress }\end{array}$ & $\begin{array}{c}\mathbf{1 , 2 7 9} \\
\text { Non-Distress } \\
\end{array}$ & $\begin{array}{c}\mathbf{1 , 0 5 8} \\
\text { Non-Distress } \\
\end{array}$ & $\begin{array}{c}\mathbf{1 , 2 7 4} \\
\text { Non-Distress }\end{array}$ & $\begin{array}{c}\mathbf{1 , 2 9 0} \\
\text { Non-Distress }\end{array}$ \\
\hline 29 & UNVR & $\begin{array}{c}\mathbf{3 , 1 0 6} \\
\text { Non-Distress }\end{array}$ & $\begin{array}{c}\mathbf{3 , 0 3 4} \\
\text { Non-Distress } \\
\end{array}$ & $\begin{array}{c}\mathbf{2 , 7 6 8} \\
\text { Non-Distress }\end{array}$ & $\begin{array}{c}\mathbf{2 , 8 1 9} \\
\text { Non-Distress }\end{array}$ & $\begin{array}{c}\mathbf{2 , 6 6 4} \\
\text { Non-Distress }\end{array}$ \\
\hline 30 & WIKA & $\begin{array}{c}\mathbf{0 , 7 9 5} \\
\text { Distress }\end{array}$ & $\begin{array}{c}\mathbf{0 , 7 4 4} \\
\text { Distress }\end{array}$ & $\begin{array}{c}\mathbf{0 , 6 4 0} \\
\text { Distress }\end{array}$ & $\begin{array}{c}\mathbf{0 , 7 3 3} \\
\text { Distress }\end{array}$ & $\begin{array}{c}\mathbf{0 , 6 2 9} \\
\text { Distress }\end{array}$ \\
\hline \multicolumn{2}{|c|}{ Rata - rata } & $\begin{array}{c}\mathbf{1 , 6 1 4} \\
\text { Non-Distress }\end{array}$ & $\begin{array}{c}\mathbf{1 , 5 5 4} \\
\text { Non-Distress }\end{array}$ & $\begin{array}{c}\mathbf{1 , 2 2 4} \\
\text { Non-Distress }\end{array}$ & $\begin{array}{c}\mathbf{1 , 2 5 6} \\
\text { Non-Distress }\end{array}$ & $\begin{array}{c}\mathbf{1 , 3 6 8} \\
\text { Non-Distress } \\
\end{array}$ \\
\hline
\end{tabular}

Berdasarkan pada tabel 6 di atas, dapat diketahui bahwa pada tahun 2013 terdapat 5 (lima) perusahaan listing pada kelompok yang masuk perhitungan saham Jakarta Islamic Index (JII) periode 2013 - 2017 dalam kondisi bangkrut (Distress) yaitu : PT. Alam Sutera Realty Tbk (ASRI), PT. Bumi Serpong Damai Tbk (BSDE), PT. Jasa Marga (Persero) Tbk (JSMR), PT. Summarecon Agung Tbk (SMRA), dan PT. Wijaya Karya (Persero) Tbk (WIKA). Sedangkan 25 perusahaan lain yang konsisten listing pada Daftar Efek Syariah dalam kelompok perusahaan yang masuk dalam perhitungan Jakarta Islamic Index (JII) periode 2013 - 2017 dalam dalam kondisi sehat (Non-Distress).

Pada tahun 2014 terdapat 5 (lima) perusahaan listing pada kelompok yang masuk perhitungan saham Jakarta Islamic Index (JII) periode 2013 - 2017 dalam kondisi bangkrut (Distress) yaitu : PT. Alam Sutera Realty Tbk (ASRI), PT. XL Axiata Tbk (EXCL), PT. Jasa Marga (Persero) Tbk (JSMR), PT. Summarecon Agung Tbk (SMRA), dan PT. Wijaya Karya (Persero) Tbk (WIKA). Sedangkan 25 perusahaan lain yang konsisten listing pada Daftar Efek Syariah dalam kelompok perusahaan yang masuk dalam perhitungan Jakarta Islamic Index (JII) periode 2013 - 2017 dalam dalam kondisi sehat (Non-Distress).

Pada tahun 2015 terdapat 9 (sembilan) perusahaan listing pada kelompok yang masuk perhitungan saham Jakarta Islamic Index (JII) periode 2013 - 2017 dalam kondisi bangkrut (Distress) yaitu : PT. Astra Agro Lestari Tbk (AALI), PT. Alam Sutera Realty Tbk (ASRI), PT. Bumi Serpong Damai Tbk (BSDE), PT. XL Axiata Tbk (EXCL), PT. Harum Energy Tbk (HRUM), PT. Jasa Marga (Persero) Tbk (JSMR), PT. PP London Sumatera Indonesia Tbk (LSIP), PT. Pakuwon Jati Tbk (PWON), dan PT. Wijaya Karya (Persero) Tbk (WIKA). Sedangkan 21 perusahaan lain yang konsisten listing pada Daftar Efek Syariah dalam kelompok 
207 AT-TAWASSUTH:Jurnal Ekonomi Islam, Volume VI No. II

Juli-Desember 2021: 189 - 212

perusahaan yang masuk dalam perhitungan Jakarta Islamic Index (JII) periode 2013 - 2017 dalam dalam kondisi sehat (Non-Distress).

Pada tahun 2016 terdapat 8 (delapan) perusahaan listing pada kelompok yang masuk perhitungan saham Jakarta Islamic Index (JII) periode 2013 - 2017 dalam kondisi bangkrut (Distress) yaitu : PT. Astra Internasional Tbk (ASII), PT. Alam Sutera Realty Tbk (ASRI), PT. Global Mediacom Tbk (BMTR), PT. XL Axiata Tbk (EXCL), PT. Jasa Marga (Persero) Tbk (JSMR), PT. Pakuwon Jati Tbk (PWON), PT. Summarecon Agung Tbk (SMRA), dan PT. Wijaya Karya (Persero) Tbk (WIKA). Sedangkan 22 perusahaan lain yang konsisten listing pada Daftar Efek Syariah dalam kelompok perusahaan yang masuk dalam perhitungan Jakarta Islamic Index (JII) periode 2013 - 2017 dalam dalam kondisi sehat (Non-Distress).

Pada tahun 2017 terdapat 9 (sembilan) perusahaan listing pada kelompok yang masuk perhitungan saham Jakarta Islamic Index (JII) periode 2013 - 2017 dalam kondisi bangkrut (Distress) yaitu : PT. AKR Corporindo Tbk (AKRA), PT. Astra Internasional Tbk (ASII), PT. Alam Sutera Realty Tbk (ASRI), PT. Charoen Pokphan Indonesia Tbk (CPIN), PT. XL Axiata Tbk (EXCL), PT. Jasa Marga (Persero) Tbk (JSMR), PT. Semen Indonesia (Persero) Tbk (SMGR), PT. Summarecon Agung Tbk (SMRA), dan PT. Wijaya Karya (Persero) Tbk (WIKA). Sedangkan 21 perusahaan lain yang konsisten listing pada Daftar Efek Syariah dalam kelompok perusahaan yang masuk dalam perhitungan Jakarta Islamic Index (JII) periode 2013 - 2017 dalam dalam kondisi sehat (Non-Distress).

Adapun secara keseluruhan tampilan perhitungan prediksi financial distress dan kebangkrutan dengan menggunakan model Springate (S-Score) berdasarkan prosentase pada perusahaan yang listing pada kelompok saham Jakarta Islamic Index (JII) periode 2013 - 2017 dapat dilihat pada tabel 7 berikut ini :

Tabel 7. Prosentase Perhitungan Model Springate (S-Score)

\begin{tabular}{|c|c|c|c|c|c|} 
Prediksi Kebangkrutan Nilai & \multicolumn{6}{|c|}{ Periode (\%) } \\
\cline { 2 - 6 } S - Score & $\mathbf{2 0 1 3}$ & $\mathbf{2 0 1 4}$ & $\mathbf{2 0 1 5}$ & $\mathbf{2 0 1 6}$ & $\mathbf{2 0 1 7}$ \\
\hline Non Distress & 83,33 & 83,33 & 70,00 & 73,33 & 70,00 \\
\hline Distress (Bankrupt) & 16,67 & 16,67 & 30,00 & 26,67 & 30,00 \\
\hline Total & $\mathbf{1 0 0 , 0 0}$ & $\mathbf{1 0 0 , 0 0}$ & $\mathbf{1 0 0 , 0 0}$ & $\mathbf{1 0 0 , 0 0}$ & $\mathbf{1 0 0 , 0 0}$ \\
\hline
\end{tabular}

(Sumber : Data Diolah, 2018) 
Berdasarkan pada tabel 7 di atas, dapat diketahui bahwa hasil prosentase prediksi kebangkrutan perusahaan listing pada kelompok yang masuk perhitungan saham Jakarta Islamic Index (JII) periode 2013 - 2017 mengalami perubahan yang cukup berarti setiap tahunnya. Prediksi distress (bankrupt) pada perusahaan tahun 2013 dan 2014 yaitu 16,67\%, kemudian mengalami peningkatan menjadi 26,67\% pada tahun 2016, dan yang paling signifikan terjadi pada tahun 2015 dan 2017 yaitu 30\%. Hasil penelitian ini sedikit berbeda dengan yang dilakukan lakukan oleh Vera Intanie Dewi dan Felisca (2011) dimana ada beberapa tipe kesalahan dalam memprediksi financial distress dan kebangkrutan suatu perusahaan dengan menggunakan model Altman (Z-Score) pada perusahaan food and beverages yang terdaftar di Bursa Efek Indonesia. Penelitian ini menggunakan sampel sebanyak 13 perusahaan, dari 15 perusahan food and beverages yang tercatat di BEI periode 2006 - 2010. Berdasarkan penelitian tersebut, diperoleh dua tipe kesalahan yang dijadikan acuan dalam penelitian yaitu : 1) kesalahan Tipe - 1, merupakan kesalahan prediksi perusahaan tidak akan pailit/baik tetapi pada kenyataannya perusahaan menjadi pailit, 2) kesalahan Tipe - 2 adalah kesalahan prediksi perusahaan akan pailit tetapi pada kenyataannya perusahaan tidak pailit. Prediksi kebangkrutan perusahaan yang konsisten listing pada Daftar Efek Syariah dalam kelompok perusahaan yang masuk dalam perhitungan saham Jakarta Islamic Index (JII) periode 2017 mengalami prosentase terbesar yaitu 30\%. Hal ini memberikan indikasi yang berbanding terbalik dengan membaiknya kondisi perekonomian global dan di Indonesia sendiri yang tampak pada kinerja Indeks Harga Saham Gabungan (IHSG) di Bursa Efek Indonesia, yang sepanjang tahun 2017 menguat 20\% ke posisi rekor tertinggi 6.355,7. Hal tersebut membuat perbaikan kondisi ekonomi Indonesia tersebut memberikan ruang bagi Bank Indonesia (BI) untuk melakukan pelonggaran moneter dengan menurunkan suku bunga acuan sebesar 4,25\% yang tercatat per Desember 2017 lalu.

\section{Kesimpulan}

Berdasarkan pada kajian yang mendalam menggunakan model Springate (S-Score) dalam memprediksi financial distress dan kebangkrutan terhadap perusahaan yang konsisten listing pada kelompok saham Jakarta Islamic Index (JII) periode 2013 - 2017 dapat diketahui berdasarkan perhitungan prediksi 
financial distress dan kebangkrutan model Springate berdasarkan pada S-Score yang telah dihitung, bahwa hasil prosentase prediksi kebangkrutan perusahaan yang konsisten listing pada kelompok perusahaan yang masuk dalam perhitungan Jakarta Islamic Index (JII) periode 2013 - 2017 mengalami perubahan yang cukup berarti setiap tahunnya. Hasil tersebut secara pasti bahwa terdapat beberapa perusahaan dalam kelompok saham Jakarta Islamic Index (JII) periode 2013 2017 yang rawan mengalami financial distress dan kebangkrutan diantaranya yaitu : PT. Alam Sutera Realty Tbk (ASRI), PT. XL Axiata Tbk (EXCL), PT. Jasa Marga (Persero) Tbk (JSMR), PT. Summarecon Agung Tbk (SMRA), dan PT. Wijaya Karya (Persero) Tbk (WIKA). Untuk itu, penelitian ini penting dilakukan dalam mengisi kesenjangan informasi mengenai kondisi keuangan perusahaan yang konsisten listing pada kelompok saham Jakarta Islamic Index (JII) periode 2013 - 2017 sehingga emiten perlu selalu mengawasi kinerja perusahaan dan menjadi bahan pertimbangan dan informasi tambahan yang akurat, jika dilihat dari laporan keuangan tahunan perusahaan yang sering mengalami penurunan pada rasio profitabilitas, maka masalah efektivitas dalam menjalankan kegiatan operasional perusahaan harus diperhatikan dengan baik dari kegiatan penjualan, pembelian dan kegiatan lainnya, sehingga mampu mengurangi terjadinya penurunan laba perusahaan, karena setiap tahunnya perusahaan dihadapkan dengan beban - beban perusahaan seperti gaji pokok karyawan, harga pokok penjualan, tuntutan pajak dan lain sebagainya, sehingga perusahaan harus mampu mencari alternatif terbaik agar perusahaan dapat terus beroperasional dan menghasilkan profit serta terhindar dari masalah likuiditas.

Selain itu, dengan penelitian ini memberikan kontribusi mengenai analisis financial distress dan kebangkrutan yang diharapkan bisa menjadi bahan pertimbangan dalam mengambil keputusan bagi para investor untuk menanamkann modal pada perusahaan yang konsisten listing pada kelompok saham yang masuk dalam perhitungan Jakarta Islamic Index (JII) sebagai salah satu alternatif investasi.

\section{Saran}

Berdasarkan hasil penelitian ini, maka dapat dikemukakan beberapa saran yaitu : 1) Bagi pihak manajemen risiko perusahaan, emiten dan para investor seharusnya mampu menyadari dan menyikapi lebih baik perusahaan yang listing 
dalam kelompok saham Jakarta Islamic Index (JII) yang mengalami gejala gelaja financial distress dan kebangkrutan dengan melakukan pengembangan dan penerapan model Springate untuk mengantisipasi masalah likuiditas yang akan terjadi sedini mungkin. Hal ini dilakukan agar dalam potensi kebangkrutan perusahaan dapat di minimalisir. Dan penulis merekomendasikan bahwa mengingat masih banyak rasio keuangan yang dapat digunakan untuk memprediksi kebangkrutan suatu perusahaan yang listing dalam kelompok saham Jakarta Islamic Index (JII) selain yang dipakai dalam penelitian ini, untuk itu penelitian selanjutnya dapat melakukan kajian dengan obyek yang lebih luas, misalnya pada ISSI (Indek Saham Syariah Indonesia) ataupun pada BEI (Bursa Efek Indonesia) agar memperoleh data yang lebih bervariasi, dan menambahkan masa perpanjangan pada jangka waktu penelitian agar mampu menghasilkan data yang lebih relevan.

\section{Endnote}

1 PT. Bank Muamalat Indonesia Tbk, Annual Report 2017, “Industry Review: Management Discussion and Analysis", Diakses melalui http://www.bankmuamalat.com, pada 17 Januari 2018, pukul 09.07 Wib

${ }^{2}$ Nurul Huda dan Mustafa Edwin Nasution, Investasi Pada Pasar Modal Syariah, Edisi Revisi, (Jakarta : Kencana, 2008), h. 55

3 Thamrin Abdullah dan Francis Tantri, Bank dan Lembaga Keuangan, (Jakarta : Rajawali Pers, 2013), h. 280

4 Monica Rahardian Ary. H, Studi Potensi Kebangkrutan Perusahaan Publik di Indonesia, Tesis, (Semarang : Pascasarjana Universitas Diponegoro, 2004), h. 2

${ }^{5}$ Kasmir, Analisis Laporan Keuangan, (Jakarta : Rajawali Pers, 2009), h. 303

${ }^{6}$ S. Munawir, Analisa Laporan Keuangan, (Yogyakarta : Liberty Yogyakarta, 2004), h. 2

${ }^{7}$ Kasmir, Analisis Laporan Keuangan, (Jakarta: Rajawali Pers, 2009), h. 7

${ }^{8}$ Sofyan Safri Harahap, Akuntansi Islam, (Jakarta : Bumi Aksara, 2004), h. 118

${ }^{9}$ Husein Syahathah, Pokok - pokok Akuntansi Islam, (Jakarta, Akbar : 2001), h. 31

${ }^{10}$ S. Munawir, Analisa Laporan Keuangan, (Yogyakarta : Liberty Yogyakarta, 2004), h.6

${ }^{11}$ Najmudin, Manajemen Keuangan dan Aktualisasi Syariah Modern, (Yogyakarta: Andi Offset), h. 65

${ }^{12}$ Ibid., h. 66

13 Sofyan Syafri Harahap, Analisis Kritis atas Laporan Keuangan, (Jakarta : RajaGrafindo Persada, 2009), h. 333

${ }^{14}$ Mamduh M. Hanafi, Manajemen Keuangan, (Yogyakarta : BPFE, 2004), h. 654

${ }^{15}$ Mamduh M. Hanafi dan Abdul Halim, Analisa Laporan Keuangan, (Yogyakarta: UUP AMP YKPN, 2005), h. 207

${ }^{16}$ Nikmah dan Dinna Dwi Sulestari, "Prediksi Financial Distress Untuk perusahaan Besar Dan Kecil di Indonesia Perbandingan Ohlson Dan Altman", Jurnal Fairness, Volume 4, Nomor 1, 2014, h. 36.

17 Arzish Shaukat dan Hinas Affandi, "Impact Of Financial Distress On Financial Performance a Study Related to Pakistan Corporate Sector", International Journal of Curret Research, Vol. 7, Issue, 02, 2015, h. 12991.

${ }^{18}$ Hanieh Shahdoust, Mohammad Reza Karimi Pouya dan Bahzed Parvizi, "A Study of Brankrupcy of Altman Adjusted and Zavgren Models in Firms Accepted in Tehran Stock Exchange (Based on Altman Adjusted Model by Kordestani and Colleagues)", World Essays Journal, 3 (2), 2015, h. 161. 
211 AT-TAWASSUTH:Jurnal Ekonomi Islam, Volume VI No. II

Juli-Desember 2021: 189 - 212

${ }_{19}$ M. Fakhri Husein dan Galuh Tri Pambekti, "Precision of the Models of Altman, Springate, Zmijewski and Grover for Predicting the Financial Distress", Journal of Economics, Business and Accountancy Ventura, Vol. 1, No. 3, 2014, h. 405.

\section{Daftar Pustaka}

Abdullah, Thamrin dan Francis Tantri, Bank dan Lembaga Keuangan, Jakarta : Rajawali Pers, 2013

Ary, Monica Rahardian H, Studi Potensi Kebangkrutan Perusahaan Publik di Indonesia, Tesis, Semarang : Pascasarjana Universitas Diponegoro, 2004

Hanafi, Mamduh M. dan Abdul Halim, Analisa Laporan Keuangan, (Yogyakarta: UUP AMP YKPN, 2005), h. 207 , Manajemen Keuangan, (Yogyakarta : BPFE, 2004), h. 654

Huda, Nurul dan Mustafa Edwin Nasution, Investasi Pada Pasar Modal Syariah, Edisi Revisi, Jakarta : Kencana, 2008

Husein, M. Fakhri dan Galuh Tri Pambekti, "Precision of the Models of Altman, Springate, Zmijewski and Grover for Predicting the Financial Distress", Journal of Economics, Business and Accountancy Ventura, Vol. 1, No. 3, 2014

Kasmir, Analisis Laporan Keuangan, Jakarta : Rajawali Pers, 2009

Munawir, S., Analisa Laporan Keuangan, Yogyakarta : Liberty Yogyakarta, 2004

Najmudin, Manajemen Keuangan dan Aktualisasi Syariah Modern, Yogyakarta: Andi Offset, (tanpa tahun)

Nikmah dan Dinna Dwi Sulestari, "Prediksi Financial Distress Untuk perusahaan Besar Dan Kecil di Indonesia Perbandingan Ohlson Dan Altman”, Jurnal Fairness, Volume 4, Nomor 1, 2014

PT. Bank Muamalat Indonesia Tbk, Annual Report 2017, “Industry Review: Management Discussion and Analysis", Diakses melalui http://www.bankmuamalat.com, pada 17 Januari 2018, pukul 09.07 Wib

Safri, Sofyan, Akuntansi Islam, Jakarta : Bumi Aksara, 2004

Shahdoust, Hanieh, Mohammad Reza Karimi Pouya dan Bahzed Parvizi, “A Study of Brankrupcy of Altman Adjusted and Zavgren Models in Firms Accepted in Tehran Stock Exchange (Based on Altman Adjusted Model by Kordestani and Colleagues)", World Essays Journal, 3 (2), 2015 
Windu Anggara: Kajian Model Springate... 212

Shaukat, Arzish dan Hinas Affandi, "Impact Of Financial Distress On Financial Performance a Study Related to Pakistan Corporate Sector", International Journal of Curret Research, Vol. 7, Issue, 02, 2015

Syahathah, Husein, Pokok - pokok Akuntansi Islam, Jakarta : Akbar, 2001

Yasser, Qaiser Rafique dan Abdullah Al Mamun, "Corporate Failure of Public listed Companies in Malaysia”, Europen Researcher, Vol. 91, No. 2, 2015 